\title{
The iron end-member of the pyrosmalite series from the Pegmont lead-zinc deposit, Queensland
}

\author{
J. P. VAUGHAN \\ Department of Mineral Exploration and Mining Geology, Western Australian School of Mines, \\ Kalgoorlie, Western Australia 6430
}

\begin{abstract}
ABs tract. Pyrosmalite $\left[(\mathrm{Mn}, \mathrm{Fe})_{8}(\mathrm{OH}, \mathrm{Cl})_{10} \mathrm{Si}_{6} \mathrm{O}_{15}\right]$ has been identified by $\mathrm{X}$-ray diffraction from the Pegmont lead-zinc deposit, north-west Queensland. Microprobe analyses indicate that it is the first reported occurrence of an extremely iron-rich member of the series. The characteristically high chlorine content of pyrosmalite in Pegmont and other similar base metal deposits may provide some evidence concerning the depositional environment of these stratiform $\mathrm{Pb}-\mathrm{Zn}$ ores.
\end{abstract}

Keywords: pyrosmalite, Pegmont $\mathrm{Pb}-\mathrm{Zn}$ deposit, Queensland, Australia.

An extremely iron-rich member of the pyrosmalite series $\left[(\mathrm{Mn}, \mathrm{Fe})_{8}(\mathrm{OH}, \mathrm{Cl})_{10} \mathrm{SiO}_{15}\right]$ has been identified from the Pegmont base metal sulphide deposit in north-west Queensland. Identification is based on optical properties, X-ray diffraction data, and microprobe analysis of a small amount of material from a diamond drill core (PD18) passing through the deposit. The $\mathrm{Fe} /(\mathrm{Fe}+\mathrm{Mn})$ ratio for the $\mathrm{Peg}$ mont material is 0.92 by far the most iron-rich pyrosmalite yet reported. Identification of this high-iron variety provides the first documented evidence that the pyrosmalite series extends into iron-rich compositions, well beyond the currently defined compositional range $[\mathrm{Fe} /(\mathrm{Fe}+\mathrm{Mn})=$ $0.15-0.59]$, and indicates that a complete solid solution series probably exists between the pure $\mathrm{Mn}$ and $\mathrm{Fe}$ end-members.

The Pegmont deposit ( $141^{\circ} 41^{\prime}$ E., $21^{\circ} 51^{\prime} \mathrm{S}$., $175 \mathrm{~km}$ south-east of Mt Isa) is a stratiform body of layered $\mathrm{Pb}-\mathrm{Zn}$ sulphides contained within a gangue of predominantly $\mathrm{Fe}$ (and $\mathrm{Mn}$ )-rich silicates, magnetite, and apatite (Stanton and Vaughan, 1979; Vaughan, 1980). The silicates are typical of a metamorphosed silicate facies iron formation sensu lato, and include knebelite, greenalite, grunerite, green hornblende, clinopyroxene and garnet. A particularly prominent feature of the Pegmont deposit is a well-developed chemical sedimentary facies pattern, in which base metal sulphide-rich iron formation grades laterally into essentially base metal sulphide-free iron formation (Stanton and Vaughan, 1979; Vaughan, 1980). Pyrosmalite appears to be restricted to the sulphide-rich central part of the orebody, a position which is also characterized by high levels of iron and manganese, but relatively low silica and alumina. The Pegmont deposit has many similarities with the larger Broken Hill deposit, New South Wales, in which more manganiferous varieties of pyrosmalite have been identified (Hutton, 1956; Stillwell and McAndrew, 1957); however, Pegmont differs significantly in that the average ratio of whole-rock $\mathrm{Fe}: \mathrm{Mn}$ is much higher than at Broken Hill.

Pyrosmalite is the name given to a relatively rare series of $\mathrm{Fe}-\mathrm{Mn}$ silicates which usually contain substantial quantities of chlorine (Winchell and Winchell, 1951). Mn-rich members of the series are relatively common (e.g. Frondel and Bauer, 1953; Stillwell and McAndrew, 1957), and the name friedelite is given to the pure $\mathrm{Mn}$ end-member which is a polytype of the series (Bauer and Berman, 1928; Frondel and Bauer, 1953). Fe-rich varieties are seldom encountered, however, with the most iron-rich analysis recorded being that given in Hintze (1897), which has $\mathrm{Fe} /(\mathrm{Fe}+\mathrm{Mn})=0.59$. The present contribution is intended to document and give preliminary $X$-ray and chemical data on a pyrosmalite occurrence in which iron content greatly exceeds that of manganese $[\mathrm{Fe} /$ $(\mathrm{Fe}+\mathrm{Mn})=0.92]$.

$X$-ray diffraction data. Table I gives the X-ray powder pattern obtained from a very small quantity of material using a modified $57.3 \mathrm{~mm}$ diameter Phillips PW1026 camera (McAndrew, 1971). The pattern obtained in Table I closely resembles that of Broken Hill material given in Stillwell and McAndrew (1957), with the exception that some of the weaker lines listed in Stillwell and McAndrew (1957) were not detected in the Pegmont pattern. After measurement and computation of $d$-spacings in the usual way, unit cell 


\begin{tabular}{|c|c|c|c|c|c|c|c|}
\hline$n_{k} \bar{i} \bar{i}$ & d calc. & d meas. & I & $h k \bar{i}$ & d calc. & d meas. & 1 \\
\hline $10 \overline{10}$ & $11.55 \AA$ & $11.58 \AA$ & 2 & $40 \overline{4} 3$ & $1.832 \AA$ & $1.833 \AA$ & 4 \\
\hline 0001 & 7.11 & 7.13 & 8 & $43 \overline{7} 1$ & 1.835 & & \\
\hline $11 \overline{20}$ & 6.70 & 6.64 & $\operatorname{tr}$ & $44 \ddot{80}$ & 1.667 & 1.667 & 4 \\
\hline $10 \overline{1} 1$ & 6.06 & 6.08 & 2 & $33 \overline{6} 3$ & 1.622 & 1.622 & 3 \\
\hline $20 \overline{2} 0$ & 5.78 & 5.78 & $\operatorname{tr}$ & $44 \overline{8} 1$ & 1.523 & & \\
\hline $11 \overline{2} 1$ & 4.865 & $4.871^{\star}$ & $\mathrm{tr}$ & $40 \overline{4} 4$ & 1.514 & 1.513 & 4 \\
\hline $20 \overline{2} i$ & 4.483 & 4.493 & $\frac{1}{2}$ & 0005 & 1.422 & 1.423 & $\frac{1}{2}$ \\
\hline $21 \overline{3} 0$ & 4.367 & 4.359 & 1 & $63 \overline{9} 1$ & 1.426 & & \\
\hline $21 \overline{3} 1$ & 3.721 & 3.728 & 1 & 1015 & 1.411 & & \\
\hline 0002 & 3.555 & 3.564 & 6 & $80 \overline{8} 1$ & 1.415 & 1.413 & 1 \\
\hline $10 \overline{1} 2$ & 3.398 & 3.399 & 2 & $61 \overline{7} 3$ & 1.414 & & \\
\hline $30 \overline{3} 1$ & 3.386 & & & $50 \overline{5} 4$ & 1.409 & & \\
\hline $22 \overline{4} 0$ & 3.335 & 3.326 & $\frac{1}{2}$ & $54 \overline{9} 2$ & 1.366 & 1.365 & 1 \\
\hline 2022 & 3.028 & 3.012 & $\frac{1}{2}$ & $44 \overline{8} 3$ & 1.364 & & \\
\hline $22 \overline{4} 1$ & 3.019 & & & $30 \overline{35}$ & 1.334 & 1.336 & 1 \\
\hline $40 \overline{4} 0$ & 2.888 & 2.889 & 1 & $80 \overline{8} 2$ & 1.338 & & \\
\hline $21 \overline{3} 2$ & 2.757 & $2.76 ?$ & $\operatorname{tr}$ & $40 \overline{4} 5$ & 1.276 & 1.276 & 1 \\
\hline $40 \overline{4} 1$ & 2.676 & 2.675 & 10 & $73 \overline{101}$ & 1.279 & & \\
\hline $30 \overline{3} 2$ & 2.612 & 2.609 & $\operatorname{tr}$ & $80 \overline{8} 3$ & 1.233 & 1.233 & $\frac{1}{2}$ \\
\hline $31 \overline{4} 2$ & 2.380 & & & & & 1.121 & $\frac{1}{2}$ \\
\hline 0003 & 2.370 & 2.374 & 1 & & & $1.083^{\star}$ & $\frac{1}{2}$ \\
\hline 4151 & 2.376 & & & & & $1.078^{*}$ & 1 \\
\hline $40 \overline{4} 2$ & 2.242 & 2.243 & 6 & & & $1.043^{\star}$ & 1 \\
\hline $11 \overline{2} 3$ & 2.333 & & & & & $0.991^{*}$ & 1 \\
\hline
\end{tabular}

* diffuse line $\quad t r=$ trace

dimensions were calculated on the basis of a hexagonal lattice, and these cell parameters were then used to calculate theoretical $d$-spacings. The cell as indexed is in good agreement with a unit cell where $a=13.33 \pm 0.03$ and $c=7.11 \pm 0.02 \AA$.

Table II gives a summary of the published compositional variation of pyrosmalite in terms of $\mathrm{Fe} /(\mathrm{Fe}+\mathrm{Mn})$, together with unit cell dimensions where measured. Although there appears to be no clear and systematic relationship between $\mathrm{Fe}$ content and cell dimensions, it is apparent that the cell dimensions of the Pegmont material are significantly smaller than those of the more manganiferous varieties listed in Table II. A decrease in cell size is consistent with increased substitution of the smaller $\mathrm{Fe}^{2+}$ ion $(0.75 \AA)$ for the larger $\mathrm{Mn}^{2+}$ ion $(0.80 \AA)$ in the pyrosmalite unit cell.

Mineral chemistry. Table III presents two microprobe analyses of ferropyrosmalite from the Pegmont deposit, together with an estimate of the number of ions in the formula unit based on a calculation which assumes the sum of $\left(\mathrm{O}^{--}+\right.$ $\mathrm{OH}^{-}+\mathrm{Cl}^{-}$) is equal to 25 . The analyses were
Table II : Summary of published pyrosmalite compositional variation $[\mathrm{Fe} /(\mathrm{Fe}+\mathrm{Mn})]$ and unit cell dimensions

\begin{tabular}{|c|c|c|}
\hline $\mathrm{Fe} /(\mathrm{Fe}+\mathrm{Mn})$ & Unit cell & Reference \\
\hline 0.15 & $\mathrm{a}=13.38, \mathrm{c}=7.15$ & Hutton (1956) \\
\hline 0.18 & $a=13.42, c=7.16$ & Watanabe et al (1961) \\
\hline 0.24 & $a=13.36, c=7.16$ & Frondel and Bauer (1953) \\
\hline 0.34 & & Stillwell and McAndrew (1957) \\
\hline 0.36 & & Ko robonoto o (1070) \\
\hline 0.38 & & Kazachencko et al (19/9) \\
\hline 0.39 & $a=13.39, c=7.18$ & Kayupova (1964) \\
\hline 0.44 & & Kazachencko et al (1979) \\
\hline 0.47 & $a=13.40, c=7.135$ & Watanabe et al (1961) \\
\hline 0.48 & & Hintze (1897) \\
\hline 0.49 & & $\begin{array}{l}\text { Hintze (1897); Costa, Barnett } \\
\text { and Kevich (1983) }\end{array}$ \\
\hline 0.51 & & Hintze (1897) \\
\hline 0.53 & & Zambonini (1901) \\
\hline 0.58 & $a=13.36, c=7.16$ & Stillwell and McAndrew (1957) \\
\hline $\begin{array}{l}0.58 \\
0.59\end{array}$ & & Hintze (1897) \\
\hline 0.92 & $a=13.33, c=7.11$ & this study \\
\hline
\end{tabular}

carried out using a MAC-400 microprobe fitted with an energy dispersive $\mathrm{X}$-ray spectrometer and a $\mathrm{Si}$ (Li-drifted) X-ray detector (accelerating voltage $15 \mathrm{kV})$. The analytical method is based on Ware (1981). Total iron is given as FeO. All major elements and chlorine were determined, however, it was not possible to measure $\mathrm{ZnO}$, a frequent minor component of most pyrosmalite analyses (e.g. Frondel and Bauer, 1953; Stillwell and McAndrew, 1957). Water has been determined by difference.

Previously reported chemical analyses of pyrosmalite are given in the references listed in Table II. Both Pegmont analyses are consistent with these earlier analyses, with the one important exception that $\mathrm{FeO}: \mathrm{MnO}$ ratios are significantly higher. $\mathrm{SiO}_{2}$ values of the Pegmont material fall between the lower value of $32.39 \%$ given in Kayupova (1964) and the upper value of $35.76 \%$ given in Hintze (1897). Chlorine values similarly fall within the quoted range of $3.58 \%$ (Hintze, 1897) to $5.63 \%$ (Watanabe et al., 1961). Structural totals for $(\mathrm{Si}+\mathrm{Al})$ and $\Sigma R^{2+}$ are in reasonable agreement with the theoretical values of 6 and 8 respectively.

Excluding the Pegmont material, the range of $\mathrm{Fe} /(\mathrm{Fe}+\mathrm{Mn})$ values for pyrosmalite as indicated in Table II extends more or less continuously from about 0.15 to 0.59 . The currently known compositional range of pyrosmalite is thus markedly 
TARLE III. Microprobe analyses of iron-rich pyrosmalite,

\begin{tabular}{lrr}
\multicolumn{3}{c}{ Pegwont deposit } \\
\hline
\end{tabular}

\begin{tabular}{|c|c|c|c|c|}
\hline Si & 5.95 & \multirow[t]{2}{*}{6.00} & \multicolumn{2}{|l|}{5.89} \\
\hline A1 & 0.05 & & \multicolumn{2}{|l|}{-} \\
\hline $\mathrm{Fe}$ & 6.97 & \multirow{3}{*}{7.80} & \multicolumn{2}{|c|}{$7.14]$} \\
\hline Mn & 0.64 & & 0.64 & \multirow[t]{2}{*}{7.94} \\
\hline $\mathrm{Mg}$ & 0.19 & & 0.16 & \\
\hline $\mathrm{Cl}$ & 1.24 & \multirow[t]{2}{*}{10.44} & 1.17 & \multirow[t]{2}{*}{10.58} \\
\hline $\mathrm{OH}$ & 9.20 & & 9.41 & \\
\hline $\mathrm{Fe} / \mathrm{Fe}+\mathrm{Mn}$ & \multicolumn{2}{|c|}{0.92} & \multicolumn{2}{|c|}{0.92} \\
\hline
\end{tabular}

+ All fe given as FeO

skewed towards Mn-rich varieties, with only a small incursion into that half of the series in which Fe exceeds Mn. Stillwell and McAndrew (1957) report a pyrosmalite from Broken Hill with $\omega=1.682$ and $\varepsilon=1.650$, close to the Pegmont material with $\omega=1.677$ and $\varepsilon=1.652$, however, it was not analysed. $\mathrm{Fe} /(\mathrm{Fe}+\mathrm{Mn})$ for the Pegmont material is 0.92 and therefore represents a considerable extension of the pyrosmalite series into extremely Fe-rich compositions. Consequently, while more data are required to fully define the complete range of pyrosmalite compositions, it now appears probable that a continuous solid solution series exists between $\mathrm{Fe} /(\mathrm{Fe}+\mathrm{Mn})$ of at least 0.15 to at least 0.92 .

$A$ note on nomenclature. Nomenclature in the pyrosmalite series is still unresolved. The name pyrosmalite was originally applied to material which contained roughly equal amounts of $\mathrm{Fe}$ and Mn (Zambonini, 1901). Frondel and Bauer (1953) proposed the name manganpyrosmalite for $\mathrm{Mn}$ rich pyrosmalite from Sterling Hill, New Jersey, and have been followed by others in this usage (Hutton, 1956; Watanabe et al., 1961). In so doing
Frondel and Bauer reserved the name pyrosmalite for that half of the series in which $\mathrm{Fe}$ exceeded $\mathrm{Mn}$, while manganpyrosmalite applied to that half in which $\mathrm{Mn}$ exceeded $\mathrm{Fe}$. This usage is also followed by Fleischer (1975). Under such a system the Pegmont material falls well within the pyrosmalite field sensu stricto.

Stillwell and McAndrew (1957), on the other hand, argue that the name manganpyrosmalite should be disregarded on the grounds that the name pyrosmalite is in consequence relegated to a species in which $\mathrm{Fe}$ exceeds $\mathrm{Mn}$, an undesirable departure from the original usage in which $\mathrm{Fe}$ approximately equalled $\mathrm{Mn}$. Further, they argue that optical distinction between $\mathrm{Mn}$-rich and $\mathrm{Fe}$ rich varieties is not practical in thin section. Optical properties of the Pegmont material confirm this latter view (except that, perhaps, Mn-rich varieties may appear brownish in thin section while Fe-rich varieties are colourless).

Petrography. Iron-rich pyrosmalite from the Pegmont deposit occurs within the main part of the ore-bearing horizon (the central position, see Stanton and Vaughan, 1979), albeit in very small amounts only. It has a platy habit with welldeveloped basal cleavage in thin section, and may occur as distinctive radiating clusters (cf. Brown, 1959). Grain size is usually of the order of 0.2 to 1 $\mathrm{mm}$, sometimes larger. The crystals are colourless in thin section, are uniaxially negative and exhibit a strong birefringence. Refractive indices were determined as $\omega=1.677 \pm 0.002$ and $\varepsilon=1.652 \pm$ 0.002 at $\lambda=589 \mathrm{~nm}$. Individual plates are usually subhedral to euhedral and appear to have a rather strong force of crystallization (cf. Stanton, 1972a, p. 640). The occasional radiating habit, which sometimes cuts across primary sedimentary layering, may therefore simply reflect this strong crystalloblastic habit in a moderately wellannealed metamorphic mineral assemblage.

The assemblage within which the pyrosmalite occurs at Pegmont includes fayalite, clinopyroxene, green hornblende, grunerite, greenalite, garnet, biotite, magnetite, apatite, galena, and sphalerite. Of these phases, it has a conspicuous association with fayalite, greenalite, and in particular, galena and sphalerite. It is often found at the margins of galena and sphalerite aggregates, usually protruding towards the interior of the sulphide grains. The association with galena and manganiferous fayalite (knebelite) has also been noted in the Broken Hill orebody (Stillwell and McAndrew, 1957).

In most cases iron-rich pyrosmalite is scattered throughout the Fe-rich silicate gangue as isolated small aggregates; however, in places it occurs in thin (1 to $2 \mathrm{~mm}$ ) submassive bands parallel to primary depositional layering in the mineralized 
iron-rich sediment. In contrast to several other reported pyrosmalite occurrences, in the Pegmont deposit it has not been observed in cross-cutting veinlets, nor is there evidence to suggest that it replaces any other silicate phase. On the contrary, the interpenetrating texture noted in pyrosmalite-galena aggregates suggests that both phases recrystallized more or less simultaneously, presumably at a relatively early stage in the history of the deposit. Taken together, all of the above suggest that pyrosmalite in the Pegmont deposit may be of prograde metamorphic origin.

Discussion. The possibility that iron-rich pyrosmalite in the Pegmont deposit is of prograde metamorphic origin may be of some importance in ore genesis studies as applied to Pegmont and other similar deposits. All of the recorded occurrences of pyrosmalite in Australia (the only occurrences with which the writer is familar) are within metamorphosed stratiform $\mathrm{Pb}-\mathrm{Zn}$ sulphide ores, invariably associated with Fe-rich or $\mathrm{Mn}$-rich silicate gangues (Broken Hill, Pegmont and at least one other deposit in the Pegmont area). Published accounts of other pyrosmalite occurrences (e.g. Frondel and Bauer, 1953; Watanabe et al., 1961; Kayupova, 1964) also indicate that the host ores are rich in Fe and $\mathrm{Mn}$ silicates and oxides, sometimes with associated base metal sulphide mineralization.

Pyrosmalite from the Broken Hill deposit has been ascribed to the late-stage replacement of anhydrous manganese silicates by a process of hydration and chlorination associated with the introduction of $\mathrm{Pb}-\mathrm{Zn}$ sulphides (Stillwell and McAndrew, 1957). They further stated that the pyrosmalite-galena association noted previously is evidence that this type of hydration and chlorination of the Mn silicates occurs at a relatively late stage with the introduction of the sulphides. The hydrothermal replacement origin of the Broken Hill lode held wide currency at that time, and an origin of the above type seemed entirely reasonable within the constraints of that particular ore genesis theory.

It is now generally agreed, however, that the Broken Hill orebody is a stratiform deposit of syngenetic origin (cf. Stanton, 1972b; Johnson and Klingner, 1975), and thus late-stage hydration and chlorination associated with replacement $\mathrm{Pb}-\mathrm{Zn}$ sulphide mineralization is not consistent with present theories in accounting for the formation of pyrosmalite. It is therefore possible that the origin of at least part of the pyrosmalite in the Broken Hill lode may have to be reinterpreted in the light of the more recent syngenetic theory (the occurrence of some pyrosmalite at Broken Hill as crystals lining rare vughs may, however, reflect local post-regional metamorphic mobilization). In particular, the pyrosmalite-galena association now supports the interpretation that pyrosmalite was formed at an early stage of the deposit's history, given that galena is now considered to be a syngenetic rather than epigenetic phase. A recent contribution by Plimer (1984) places pyrosmalite at Broken Hill in the 'waning metamorphic stage', and attributes its formation to the reaction of metamorphic fluids with early formed minerals during the high-grade metamorphic stage. Similar arguments may apply to other pyrosmalite occurrences, some of which were once regarded as replacement deposits, but are now generally held to be stratiform syngenetic deposits (e.g. Sterling Hill, New Jersey).

As noted above, there is reasonable evidence to suggest a prograde metamorphic origin for ironrich pyrosmalite from Pegmont, and the same may hold for at least part of the Broken Hill pyrosmalite. In this context it is interesting to note that Watanabe et al. (1961) refer to pyrosmalite in the Kyurazawa mine as replacing chert along bedding planes. In view of currently accepted ideas generally discounting the selective replacement of thins beds within pre-existing sedimentary ores, however, it is perhaps possible that this may reflect an original layering rather than a replacement texture. If pyrosmalite, in at least some of these deposits, is indeed of prograde metamorphic origin, it is suggested that the high chlorine content may reflect the extremely $\mathrm{Cl}$-rich environment (metalliferous brines?), rather than a retrogressive breakdown of anhydrous $\mathrm{Fe}-\mathrm{Mn}$ silicates in areas locally enriched in late-stage water and chlorine. Finally, it is suggested that in some cases pyrosmalite may have ultimately been derived from the metamorphism of some form of primitive Cl-bearing, Fe-rich gel or clay precursor (cf. Stanton, 1982).

Acknowledgements. The author wishes to thank Messrs B. Robinson and R. Walker (CSIRO) for assistance with microprobe analyses, Dr J. McAndrew (CSIRO) for assistance with XRD techniques, and Dr E. H. Nickel (CSIRO) for assistance with refractive index determinations. Dr A. Graham (WA School of Mines) gave additional advice concerning XRD data. Professor R. L. Stanton, Dr J. McAndrew and Dr E. H. Nickel gave helpful advice on an early draft of the manuscript. Mrs J. Mills and Mrs C. Rankine kindly typed the manuscript. Financial support from Newmont Pty. Ltd. and a Commonwealth Postgraduate Award is gratefully acknowledged.

\section{REFERENCES}

Bauer, L. H., and Berman, H. (1928) Am. Mineral. 13, 341-8.

Brown, P. E. (1959) Mineral. Mag. 32, 242-4.

Costa, U. R., Barnett, R. L., and Kerrich, R. (1983) Econ. Geol. 78, 1144-203. 
Fleischer, M. (1975) Glossary of Mineral Species. Mineralogical Record Inc., Bowie, Maryland.

Frondel, C., and Bauer, L. H. (1953) Am. Mineral. 38, $755-60$.

Hintze, C. (1897) Handbuch der Mineralogie, 2, 510-14. Hutton, C. O. (1956) Am. Mineral. 41, 581-91.

Johnson, I. R., and Klingner, G. D. (1975) In Economic

Geology of Australia and Papua New Guinea-I. Metals, (C. L. Knight, ed.) Australas. Inst. Min. Metall., Melbourne, Australia, pp. 476-91.

Kayupova, M. M. (1964) Dokl. Akad. Nauk SSSR, 159, $82-5$.

Kazachencko, V. T., Narnov, G. A., Chubarov, V. M., Shcheka, Zh. A., and Romanenko, I. M. (1979) Neues Jahrb. Mineral. Abh. 137, 20-41.

McAndrew, J. (1971) Clay Minerals, 9, 253-7.

Plimer, I. R. (1984) Austral. J. Earth Sci. 31, 379-402.

Stanton, R. L. (1972a) Ore Petrology, McGraw-Hill, New York.
- (1972b) Econ. Geol. 67, 1128-45.

_-(1982) Trans. Inst. Min. Metall. Sect. B, 91, 72-9.

and Vaughan, J. P. (1979) Proc. Australas. Inst. Mining Metall. 270, 25-38

Stillwell, F., and McAndrew, J. (1957) Mineral. Mag. 31, 371-80.

Vaughan, J. P. (1980) Ph.D. thesis, University of New England, Armidale, Australia.

Ware, N. G. (1981) Computers and Geosciences, 7, 167-84. Watanabe, T., Kato, A., and Ito, J. (1961) Mineral. J. 3, 130-8.

Winchell, A. N., and Winchell, H. (1951) Elements of Optical Mineralogy, Part II, 4th edn., Wiley, New York, p. 359.

Zambonini, F. (1901) Z. Krystallogr. Mineral. 34, 554-61.

[Manuscript received 18 September 1984;

revised 26 June 1985] 